Original Research Article

\title{
A study on determinants of adherence to highly active anti-retroviral therapy in a tertiary care hospital
}

\author{
Sandeep B. ${ }^{1 *}$, Suraj.B. ${ }^{2}$
}

${ }^{1}$ Department of Pharmacology, GIMSR, Visakhapatnam, India ${ }^{2}$ Department of Pharmacology, ESIC Medical College and hospital, Gulbarga, India

Received: 15 September 2016 Accepted: 20 October 2016

\section{*Correspondence to: \\ Dr. Sandeep B., \\ Email: sandeeppanchal72@ gmail.com}

Copyright: (C) the author(s), publisher and licensee Medip Academy. This is an openaccess article distributed under the terms of the Creative Commons Attribution NonCommercial License, which permits unrestricted noncommercial use, distribution, and reproduction in any medium, provided the original work is properly cited.

\begin{abstract}
Background: Acquired immunodeficiency syndrome (AIDS) caused by human immunodeficiency virus (HIV) is a major global health problem. A major concern with scaling up of antiretroviral treatment in resource limited settings is the emergence of drug resistant viral strains due to sub-optimal adherence and the transmission of these resistant viral strains in the population. Adherence is the second largest predictor of progression to AIDS and death after CD4 count. Hence the aim of the present study was to evaluate adherence to HAART and its determinants among HIV/AIDS patients on first line HAART.

Methods: This study was cross-sectional, observational in nature carried out among two hundred and seventy (270) HIV/AIDS patients on HAART during December 2013 to November 2014 at ART centre. Frequencies, Proportions and logistic regression analysis were applied and statistical analysis was done using (SPSS) 17.0 version.

Results: Among the study population, $52.6 \%$ of the patients were male, $81.5 \%$ of them were adherent to HAART in the last 7 days recall. Most common reasons for missing HAART regimen in this study were simply forgetting (70\%). On Bivariate analysis, Adherence levels was less among Female (p $<0.025)$ compared to male patients, Adherence levels were more among patients who were Employed ( $\mathrm{p}<0.01$ ) compared to unemployed, patients taking only HAART medications $(\mathrm{p}<0.000)$ when compared to patients taking more than or equal to four medications, those taking two to three medications ( $p<0.000$ ) when compared to patients taking more than or equal to four medications, patients in WHO stage I ( $\mathrm{p}<0.00)$ compared to patients in WHO stage III, patients in WHO stage II ( $\mathrm{p}<0.032$ ) compared to patients in stage III and lastly patients who were never admitted to hospital ( $\mathrm{p}<0.008)$ due to HIV related illness in the previous year of HAART medication compared to those admitted more than once.

Conclusions: Several demographic and treatment related factors influence adherence to HAART. Hence, addressing these factors and providing adherence support services are main strategies to decrease non-adherence and its consequences.
\end{abstract}

Keywords: Adherence, Drug resistance, HIV/AIDS, Mortality, Opportunistic infections, Suboptimal-adherence

\section{INTRODUCTION}

HIV/AIDS is a major global health problem. According to HIV sentinel surveillance (2012-13), the HIV prevalence in the general population was $0.35 \%$ in India. ${ }^{1}$ Adherence is the second largest predictor of progression to AIDS and death after CD4 count. $^{2}$ Estimates of average rates of adherence with HAART in India range from $73 \%$ to $95 \%$ in many different social and cultural settings and the risks associated with non-adherence are extensive at both individual and social levels. ${ }^{3-5}$ Hence the present study was conducted to evaluate determinants of adherence to HAART among HIV/AIDS infected individuals.

\section{METHODS}

A cross-sectional observational study was conducted from December 2013 to November 2014 at ART center 
staffed with health professionals trained in ART treatment and adherence counselling services.

\section{Study design}

This study was cross-sectional; observational in nature and started after obtaining approval from Institutional Ethics Committee. Patients of either sex aged more than or equal to 18 years infected with HIV and on ART treatment for a minimum period of 6 month and willing to provide consent were included in the study. Patients aged less than 18 years infected with HIV but not on ART and having been on ART for less than 6 month duration and unwilling to provide consent were excluded.

\section{Data collection}

Prior to the start of actual data collection, the data collection format and the whole method were screened on randomly selected patient clinical records, at the ART Center to ensure their completeness. Adult AIDS Clinical Trials Group (AACTG), semi-structured questionnaire was adopted which was pre-structured and pre-tested containing questions to collect data on Sociodemographic profile, Self-report on Adherence, Reasons for missing dose. Variables related to ART medication, laboratory values, clinical staging and CD4 cell count were obtained from patient treatment records.

\section{Definitions}

Adherence is defined as Patients living with HIV and AIDS (PLHA) who had taken $\geq 95 \%$ of the prescribed doses. Patients who had reported missed doses were asked to provide reasons for missing their medications. To minimize recall bias, we asked PLHA to indicate their adherence over the previous four days, previous week, previous month and previous three month successively.

\section{Data analysis}

Frequencies, Proportions and logistic regression analysis were applied. All data collected were analysed using SPSS, version 17.0 software.

\section{RESULTS}

A total of $270 \mathrm{HIV/AIDS}$ patients were on HAART during the study period. Among the patients on HAART a total of $142(52.6 \%)$ were males, $135(50 \%)$ were aged less than or equal to 40years, $194(71.9 \%)$ were from the rural area. With regards to the educational background, the majority of the patients $190(70.4 \%)$ were literate. The duration of ART less than or equal to 2years were 85 $(68.5 \%)$ patients, a CD4 cell count more than 350 cells/mm3 were $85(68.5 \%)$ patients (Table 1$)$.

The study respondents adherent to HAART regimen over previous 4 days recall were $240(88.9 \%)$ patients, over 7 days recall were $220(81.5 \%)$ patients. However, as the duration of recall increased we found increase in the adherence levels among respondents. The adherence level to HAART regimen over previous 1 month recall was 225 $(83.3 \%)$ and lastly over 3month recall was $245(90.7 \%)$ patients (Table 2).

Table 1: Descriptive analysis of socio-demographic, clinical variables of the participants on HAART.

\begin{tabular}{|c|c|c|}
\hline \multirow{21}{*}{$\begin{array}{l}\text { Socio- } \\
\text { demographic } \\
\text { variables }\end{array}$} & Variables & n $(\%)^{*}$ \\
\hline & \multicolumn{2}{|l|}{ Age (years) } \\
\hline & $20-29$ & $45(16.7)$ \\
\hline & $30-39$ & $90(33.3)$ \\
\hline & $40-49$ & $85(31.5)$ \\
\hline & $50-59$ & $37(13.7)$ \\
\hline & $60-69$ & $09(3.3)$ \\
\hline & $\geq 70$ & $04(1.5)$ \\
\hline & \multicolumn{2}{|l|}{$\overline{\text { Education }}$} \\
\hline & Illiterate & $80(29.6)$ \\
\hline & Primary & $65(24.1)$ \\
\hline & Secondary & $50(18.5)$ \\
\hline & High school & $40(14.8)$ \\
\hline & Pre university & $20(7.4)$ \\
\hline & Degree & $15(5.6)$ \\
\hline & \multicolumn{2}{|l|}{ Gender } \\
\hline & Male & $142(52.6)$ \\
\hline & Female & $128(47.4)$ \\
\hline & \multicolumn{2}{|l|}{$\begin{array}{l}\text { Place of } \\
\text { residence }\end{array}$} \\
\hline & Rural & $194(71.9)$ \\
\hline & Urban & $76(28.1)$ \\
\hline \multirow{5}{*}{ Clinical variables } & $\begin{array}{l}\text { Duration on } \\
\text { ART }(\leq 2 \\
\text { years })\end{array}$ & $185(68.5)$ \\
\hline & \multicolumn{2}{|c|}{$* *$ CD4 level $\left(\right.$ cells $\left./ \mathrm{mm}^{3}\right)$} \\
\hline & $101-200$ & $10(3.7)$ \\
\hline & $201-350$ & $75(27.8)$ \\
\hline & $>350$ & $185(68.5)$ \\
\hline
\end{tabular}

*Frequency and proportions, total number of participants $(\mathrm{N}=$ 270); **Most recent CD4 level (cells $/ \mathrm{mm}^{3}$ ).

Table 2: Levels of adherence over different time periods of recall.

\begin{tabular}{|lll|}
\hline $\begin{array}{l}\text { Period of } \\
\text { recall }\end{array}$ & $\begin{array}{l}\text { Adherent } \\
\mathbf{n}(\boldsymbol{\%})\end{array}$ & $\begin{array}{l}\text { Non-adherent } \\
\mathbf{n}(\boldsymbol{\%})\end{array}$ \\
\hline Previous 4 days & $240(88.9 \%)$ & $30(11.1 \%)$ \\
\hline Previous 7 days & $220(81.5 \%)$ & $50(18.5 \%)$ \\
\hline $\begin{array}{l}\text { Previous 1 } \\
\text { month }\end{array}$ & $225(83.3 \%)$ & $45(16.7 \%)$ \\
\hline $\begin{array}{l}\text { Previous 3 } \\
\text { months }\end{array}$ & $245(90.7 \%)$ & $25(9.3 \%)$ \\
\hline
\end{tabular}

*PLHA (People living with HIV/AIDS); **Frequency and proportions, total number of participants $(\mathrm{N}=270)$.

Most common reasons for missing HAART regimen in this study were simply forgetting, contributing to 35 
(70\%) patients, side effects in $17(34 \%)$ patients (Table 3).

On Bivariate analysis, Adherence level was less among female $[(\mathrm{p}<0.025), 95 \% \mathrm{CI}(0.510)]$ compared to male whereas Adherence level were more among ART patients who were Employed [( $\mathrm{p}<0.01)$, 95\% CI (3.070)] compared to unemployed, Patients taking only ART medications [( $\mathrm{p}<0.000,95 \% \mathrm{CI}(7.885)]$ compared to patients taking more than or equal to four medications, patients taking two to three medications $[(\mathrm{p}<0.000,95 \%$ CI (6.895)] compared to patients taking more than or equal to four medications, Patients in WHO stage I [ $(\mathrm{p}$ $<0.00), 95 \%$ CI (10.685)] compared to patients in WHO stage III, patients in stage II $[(\mathrm{p}<0.032,95 \%$ CI $(2.745)]$ compared to patients in WHO stage III, patients who were never admitted to hospital $[(\mathrm{p}<0.008)$, 95\% CI (4.311)] due to HIV/AIDS related illness in the previous one year of ART medication compared to those admitted more than once (Table 4).

Table 3: Reasons for missing ART dose is repeated in the table twice.

\begin{tabular}{|ll|}
\hline $\begin{array}{l}\text { Reasons for missing } \\
\text { ART dose }\end{array}$ & $\begin{array}{l}\text { Number of Responses } \\
(\mathbf{N}=\mathbf{5 0}) *\end{array}$ \\
\hline Simply forgot & $35(70 \%)$ \\
\hline Side effects & $17(34 \%)$ \\
\hline Change in routine & $12(24 \%)$ \\
\hline Busy with other things & $10(20 \%)$ \\
\hline Was away from home & $10(20 \%)$ \\
\hline
\end{tabular}

*Shows the reasons for missing ART/doses $(\mathrm{N}=50)$; Multiple responses for missing ART dose were allowed.

Table 4: Logistic regression analysis of selected variables and adherence to ART.

\begin{tabular}{|c|c|c|c|c|}
\hline Variables & & $\begin{array}{l}\text { Adherent } \\
(\mathrm{N}=\mathbf{2 2 0})^{\$}\end{array}$ & $\begin{array}{l}\text { Bivariate analysis } \\
\text { OR }(95 \% \mathrm{CI}) *\end{array}$ & P value \\
\hline \multirow{2}{*}{ Gender } & Female & 98 & $0.510(0.282-0.926)$ & \multirow{2}{*}{0.025} \\
\hline & Male & 122 & 1.0 & \\
\hline \multirow{2}{*}{ Employed } & Yes & 192 & $3.070(1.455-6.295)$ & \multirow{2}{*}{0.001} \\
\hline & No & 28 & 1.0 & \\
\hline \multirow{3}{*}{$\begin{array}{l}\text { Number of } \\
\text { medications }\end{array}$} & One & 52 & $7.885(3.071-20.250)$ & 0.000 \\
\hline & Two to Three & 137 & $6.895(3.340-14.220)$ & \multirow{2}{*}{0.000} \\
\hline & Four and above & 31 & 1.0 & \\
\hline \multirow{3}{*}{$\begin{array}{l}\text { Number of } \\
\text { hospitalization }\end{array}$} & Never & 140 & $4.311(1.566-11.771)$ & 0.008 \\
\hline & Once & 62 & $1.600(0.537-4.750)$ & \multirow{2}{*}{0.388} \\
\hline & More than once & 18 & 1.0 & \\
\hline \multirow{3}{*}{ ** WHO staging } & Stage I & 161 & $10.685(4.096-27.877)$ & 0.000 \\
\hline & Stage II & 50 & $2.745(1.065-7.088)$ & \multirow[b]{2}{*}{0.032} \\
\hline & Stage III & 09 & 1.0 & \\
\hline
\end{tabular}

$\$$ Adherence level; * OR (95\% CI): Odds Ratio (95\% confidence interval); ** Most recent WHO staging.

\section{DISCUSSION}

It was reported that, $88.9 \%$ (240) of the study respondents were adherent to HAART over previous 4 days recall and $81.5 \%(220)$ of the study respondents were adherent to the regimen over previous 7 days recall. However, as the period of recall increased we found increase in levels of adherence among respondents, over one month recall $83.3 \%$ (225) and on 3 month recall $90.7 \%$ (245) of the respondents were adherent. Therefore, adherence levels of previous one week recall were taken into considerations to avoid recall bias. The rates of adherence in this study were in the range of $(73 \%-95 \%)$ which were found to be consistent to the studies conducted by Kumarsamy $\mathrm{N}$ et $\mathrm{al}^{3}$, Shaw B et al, ${ }^{4}$ and Sarna et $\mathrm{al}^{5}$ in India. Adherence rate of $81.5 \%$ in this study is still a matter of concern as $18.5 \%$ of non- adherent patient are at risk of treatment failure and transmission of resistance virus to the community.

The most common reasons for missing HAART regimen in this study were simply forgetting (70\%). This finding was found to be consistent to the study done by Heckman BD et al. ${ }^{6}$

Adherence levels was less among Female [(p <0.025), 95\% CI (0.510)] compared to male patients and was consistent with longitudinal study conducted by Godin $\mathrm{G}$ et al. ${ }^{7}$

Adherence levels were more among ART patients who were Employed [( $<<0.01), 95 \%$ CI (3.070)] compared to those who were unemployed and was consistent with results by Sarna et $\mathrm{al}^{5}$ and Afolabi MO et al. ${ }^{8}$ 
Adherence levels were more among patients taking only ART medications [ $(\mathrm{p}<0.000,95 \%$ CI $(7.885)]$ compared to those taking more than or equal to four medications and among those taking two to three medications [(p $<0.000,95 \%$ CI (6.895)] when compared to those patients taking more than or equal to four medications. Many studies around the world reported $>4$ medications at present and higher pill burden were also major predictors of non-adherence. ${ }^{9,10,11}$

Adherence levels were more among patients in WHO stage I $[(p<0.00), 95 \%$ CI $(10.685)]$ when compared to patients in stage III, patients in WHO stage II $[(\mathrm{p}<0.032$, $95 \%$ CI (2.745)] when compared to patients in stage III and were consistent with results by Sarna et al. ${ }^{5}$

Adherence levels were more among ART patients who were never admitted to hospital [(p<0.08), $95 \% \mathrm{CI}$ (4.311)] due to HIV related illness in the previous 1year of ART medication compared to those admitted more than once and were consistent with a study conducted by Sarna et al. ${ }^{5}$

The confidentiality of the data obtained was assured and no disclosure was made of any name of the patients, the healthcare provider or drug product in relation to the finding.

\section{ACKNOWLEDGEMENTS}

The authors would like to express their appreciation to the staff of ART center RIMS teaching hospital, Raichur for their kind cooperation during data collection and staff of ESIC College and Hospitals, Gulbarga for their scientific inputs.

Funding: No funding sources

Conflict of interest: None declared

Ethical approval: The study was approved by the Institutional Ethics Committee (protocol number: IEC/PG/2012/04)

\section{REFERENCES}

1. HIV Sentinel Surveillance 2012-13: A Technical brief. Available from URL: http://www.naco.gov.in. 2012.

2. Hogg RS, Heath K, Bangsberg D, Yip B, Press N, O'Shaughnessy MV et al. Intermittent use of triplecombination therapy is predictive of mortality at baseline and after 1 year of follow-up. AIDS. 2002;16:1051-8.

3. Safren SA, Kumarasamy N, James R, Raminani R, Solomon S, Mayer KH. ART adherence, demographic variables and CD4 outcome among HIV positive patients on antiretroviral therapy in Chennai, India. AIDS Care. 2005;17:853-62.

4. Shah B, Walshe L, Saple DG, Mehta SH, Kharkar RD, Gupta A et al. Adherence to antiretroviral therapy and virologic suppression among HIVinfected persons receiving care in private clinics in Mumbai, India. Clinical Infectious Diseases. 2007;44:1235-44.

5. Sarna A, Pujari S, Sengar AK, Garg R, Gupta I, Vandem J. Adhernce to antiretroviral therapy and its determinants amongst HIV patients in India. Indian $\mathbf{J}$ Med Res. 2008;127:28-36.

6. Heckman BD, Catz SL, Heckman TG, Miller JG, Kalichman SC. Adherence to antiretroviral therapy in rural persons living with HIV disease in the United States. AIDS Care. 2004;16:219-30.

7. Godin G, Cote J, Naccache H, Lambert D, Trottier S. Prediction of adherence to antiretroviral therapy: A one-year longitudinal study. AIDS Care. 2005; 17:493-504.

8. Afolabi MO, Ijadunola KT, Fatusi AO, Olasode OA. Determinants of adherence to antiretroviral drugs among people living with HIV/AIDS in the Ife-Ijesa zone of Osun state, Nigeria. Afr J Prm Health Care Fam Med. 2009;1:6.

9. Souleymane D, Michel A, Kanga KC. Determinants of adherence to highly active antiretroviral therapy among HIV-1-infected patients in Cote d'Ivoire. AIDS. 2007;21:1799-803.

10. Tadios Y, Davey G. Antiretroviral treatment adherence and its correlates in Addis Ababa, Ethiopia. Ethiop Med J. 2006;44:237-44.

11. Sullivan PS, Campsmith ML, Nakamura GV, Begley EB, Schulden J, Nakashima AK. Patient and regimen characteristics associated with self-reported nonadherence to antiretroviral therapy. PLoS ONE. $2007 ; 2$.

Cite this article as: Sandeep B, Suraj B. A study on determinants of adherence to highly active antiretroviral therapy in a tertiary care hospital. Int J Basic Clin Pharmacol 2016;5:2594-7. 